\title{
Pengawasan Biaya Operasional pada UD. Saroha Serbelawan
}

\author{
Eko Deswin Miechaels Siringo-ringo ${ }^{1}$ \\ Sekolah Tinggi Akuntansi dan Manajemen \\ Indonesia \\ ekodeswin10@yahoo.com \\ Nancy Florida Siagian ${ }^{3}$ \\ Politeknik Bisnis Indonesia \\ Siagiannancyflorida@gmail.com
}

\author{
Mega Romauly Tampubolon ${ }^{2}$ \\ Sekolah Tinggi Akuntansi dan Manajemen \\ Indonesia \\ mega9ntar@yahoo.com \\ Felicia $^{4}$ \\ Sekolah Tinggi Akuntansi dan Manajemen \\ Indonesia \\ Feli.cia@gmail.com
}

\begin{abstract}
For companies engaged in providing services, operational costs are a very influential element for the formation of corporate profits. Similarly, the UD. Saroha Serbelawan, so that the management and use of operational costs in this company are always monitored from period to period with a continuous monitoring system to maintain the creation of efficiency and effectiveness of work and to see the responsibility of each part in the deviation that occurs in the use of operational costs. After conducting a review and research on UD. Saroha Serbelawan, it can be seen that in the period of 2004 the company experienced a problem, namely the realization of operating costs in 2004 deviated from a sufficient amount of material from the company's operating budget. "To prove the truth and reality of the company, direct research is carried out in the field to obtain data related to the problem and then conduct library research to obtain theoretical materials as a basis for analyzing and evaluating problems that occur. As for suggestions - suggestions that can be made on the conclusions of the problem that occurs is that in each preparation of operational costs should the company conduct a more careful study of all factors that affect operational costs both internal and external factors and then followed up by increasing supervision of management and use of operational costs, mainly through accounting oversight by creating a more in-company accounting system.
\end{abstract}

Keywords: Providing Services, Operational Costs, Corporate Profits, Monitoring System, Analyzing and Evaluating

\section{PENDAHULUAN}

\subsection{Latar Belakang Penelitian}

Seiring dengan semakin merosotnya pertumbuhan ekonomi dalam negeri dalam lima tahun terakhir ini maka setiap perusahaan dituntut untuk dapat beroperasi secara lebih efektif, efisien dan ekonomis. Hal ini bertujuan agar setiap perusahaan tersebut dapat menjaga kelangsungan hidup usahanya dan sekaligus supaya dapat bersaing dengan perusahaan perusahaan lain dalam persaingan yang lebih ketat.

Seorang pimpinan perusahaan diharapkan dapat mengelola sumber daya - sumber daya yang dimiliki perusahaan dan menjalankan aktivitas operasionalnya dalam suatu kinerja yang baik dan terorganisir. (George R. Terry , 1993) menyatakan Penilaian mencakup usaha - usaha mengendalikan, yakni mengevaluasi pelaksanaan kegiatan dan (bila perlu) memperbaiki kegiatan - kegiatan yang telah dilaksanakan untuk mendapatkan kepastian mencapai hasil yang direncanakan.

Untuk dapat melaksanakan itu semua, maka seorang pimpinan perusahaan harus dapat merencanakan, mengkoordinir, mengawasi serta mengendalikan segala aktivitas atau 
kegiatan perusahaan untuk menghindari halhal yang merugikan perusahaan.

Aktivitas atau kegiatan sehari-hari yang terjadi dalam suatu perusahaan umumnya selalu berhubungan dengan biaya - biaya. Biaya - biaya inilah yang disebut dengan biaya operasi, dan lebih lanjut penggunaan biaya operasi merupakan dasar bagi penilaian efisiensi kinerja suatu perusahaan. (Adolph Matz dan Milton F. Usry , 1991) menyatakan "Pengendalian (control) merupakan usaha sistematis perusahaan untuk mencapai tujuan dengan cara membandingkan prestasi kerja dengan rencana. Kegiatan harus terus menerus diawasi jika manajemen ingin tetap berada dalam batas ketentuan yang telah digariskan. Hasil nyata dari setiap kegiatan dibandingkan dengan rencana dan bila terdapat perbedaan besar akan diambil tindakan perbaikan". Untuk mencegah dan mengatasi terjadinya penyimpangan atau inefisiensi dalam penggunaan biaya operasi, maka diperlukan suatu bentuk pengawasan atas biaya operasi dan penggunaan sumber daya - sumber daya milik perusahaan. Hal ini perlu dilakukan agar setiap pimpinan perusahaan dapat mempertanggungjawabkan setiap penggunaan biaya operasi sehubungan dengan usaha pencapaian efisiensi dalam suatu perusahaan.

\subsection{Pengawasan Biaya Operasional Pada UD. Saroha Serbelawan.}

UD. Saroha merupakan perusahaan perseorangan yang bergerak di bidang jasa konstruksi. Perusahaan perseorangan ini didisirikan oleh David pada tahun 1962 yang awalnya menggunakan nama Dos Roha dan berkedudukan di Perdagangan. Pada awalnya perusahaan perseorangan Dos Roha ini hanya beroperasi di bidang bahan bangunan dan pada saat itu hanya melayani permintaan penduduk setempat.

Pada tahun 1967 perusahaan perseorangan Dos Roha ini berubah menjadi bentuk UD. Saroha. Selanjutnya, pada tahun 1983 kedudukan David sebgai direktur pada UD. Saroha digantikan oleh Johan dan berlangsung hingga kini.

Struktur organisisi yang ditetapkan oleh UD. Saroha adalah struktur organisasi berbentuk garis dan staf, karena garis perintah mengalir dari atas, yaitu dari pimpinan atas kepada tingkat pegawai yang paling bawah dan sebaliknya tanggungjawab adalah dari pegawai yang paling rendah kepada pimpinan, dan dalam pelaksanaannya fungsi garis dibantu oleh fungsi staf yang bertugas memberi saran dan memberi pelayanan kepada fungsi garis. Sistem orgasnisasi yang baik dan teratur dapat mempermudah pimpinan untuk mengkoordinir dan mengawasi tugas yang dilaksanakan oleh setiap bawahan sehingga usaha untuk mencapai tujuan akan lebih mudah sesuai rencana yang telah ditetapkan.

\section{STRUKTUR ORGANISASI UD. SAROHA SERBELAWAN :}

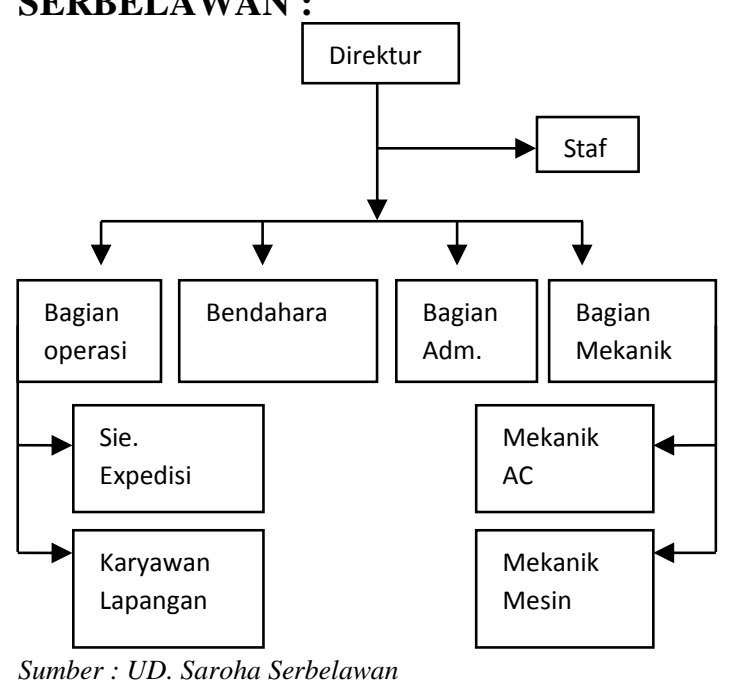

Elemen - elemen biaya operasional pada UD. Saroha Serbelawan adalah sebagai berikut :

1. Gaji dan Upah

2. Biaya Pemasaran

3. Biaya Adminitrasi dan Umum

4. Biaya Penyusutan

Pengawasan biaya operasional pada UD. Saroha Serbelawan dilakukan dengan suatu alat pengawasan yaitu anggaran. Anggaran biaya operasional merupakan dasar atau pedoman dari pelaksanaan yang sesungguhnya dalam perusahaan, sehingga anggaran mempunyai peranan penting dalam setiap fungsi pengawasan. (Robert N. Anthony , 1990) menyebutkan bahwa "Anggaran (budget) adalah rencana manajemen, dengan 
anggapan bahwa penyusunan anggaran akan mengambil langkah - langkah positif untuk merealisasi rencana yang telah disusun". Dan lebih rinci, (M. Nafarin, 2000) mengatakan bahwa: "Anggaran (budget) merupakan rencana tertulis mengenai kegiatan suatu organisasi yang dinyatakan secara kuantitatif dan umumnya dinyatakan dalam satuan uang untuk jangka waktu tertentu".

Selama pelaksanaan aktivitasnya, kondisi lingkungan perusahaan juga mempengaruhi aktivitas perusahaan tersebut, dan ini juga tentunya akan mempengaruhi besarnya biaya operasional yang digunakan oleh perusahaan. Perubahan - perubahan jumlah biaya operasional dari yang sudah dianggarkan, terus dimonitor dan direkam dalam bentuk catatan - catatan akuntansi, agar segera dapat dilaporkan.

Berikut ini adalah tahapan dan prosedur pengeluaran dana anggaran biaya operasional yang disajikan dalam bentuk bagan arus :

Bagian-Bagian Bagian Adm. Bendahara Direktur Perusahaan

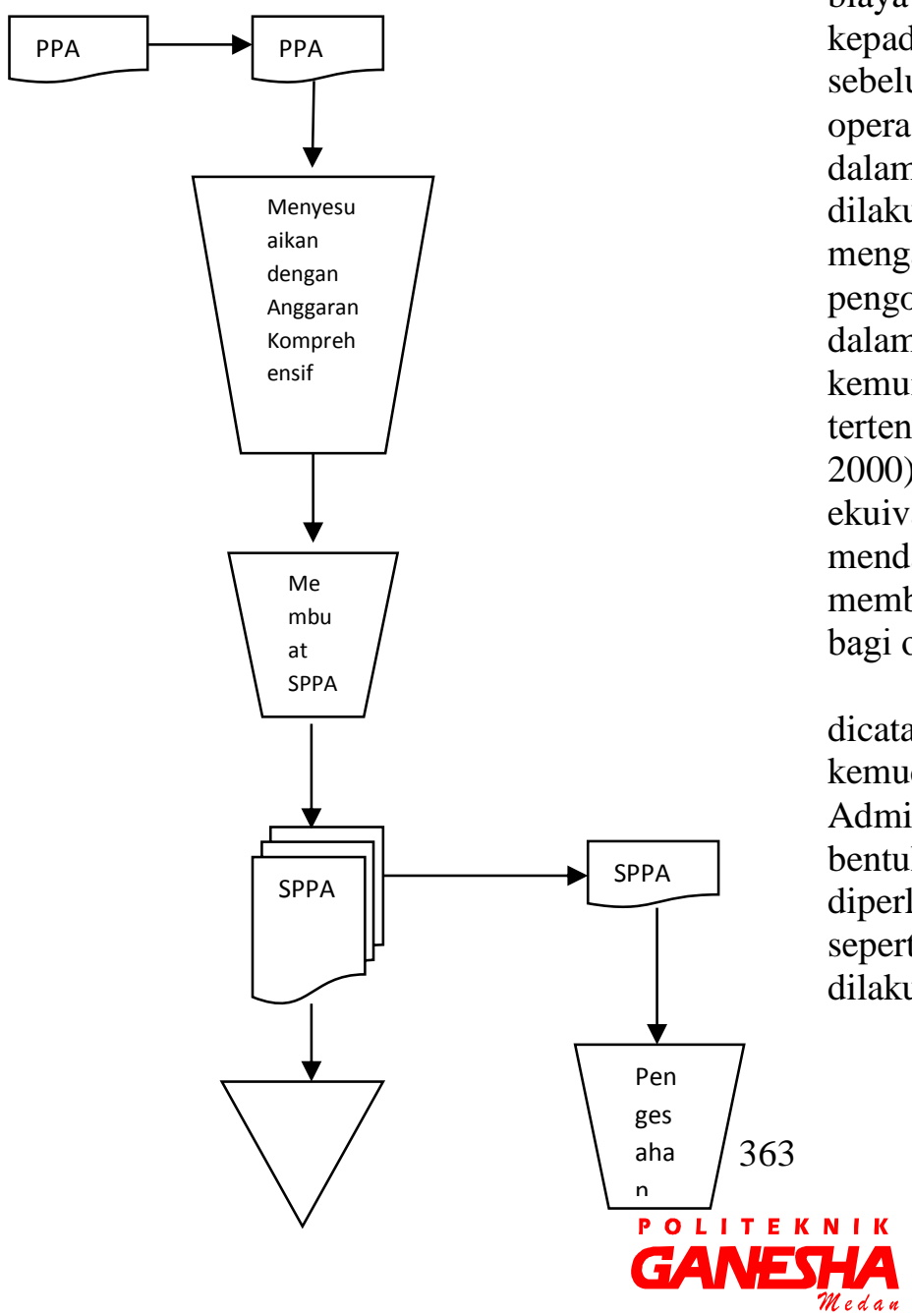

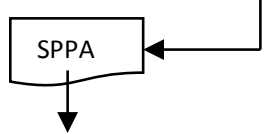

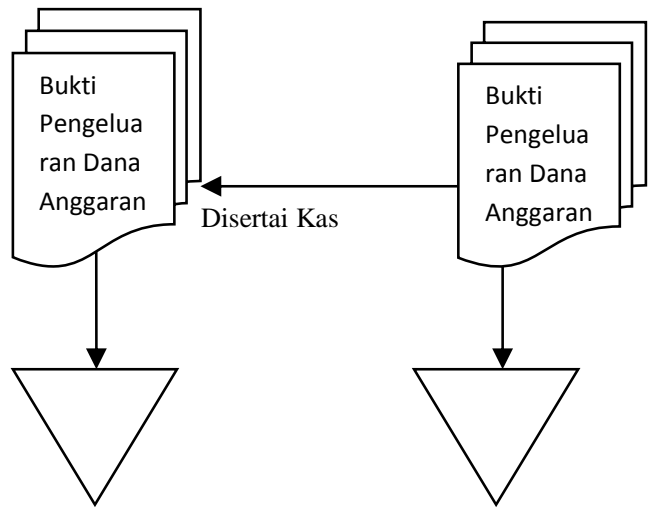

Sumber : UD. Saroha Serbelawan

Dalam pelaksanaan masing - masing bagian diberikan otorisasi dalam penggunaan dana anggaran biaya operasional yang diterima, tetapi tentu saja pengeluaran dana biaya operasional ini harus berpedoman kepada anggaran yang telah disusun sebelumnya. Adapun pengeluaran biaya perasional pada masing - masing bagian alam kegiatan operasional perusahaan masih ilakukan dengan uang tunai. (Mulyadi , 1990) engatakan bahwa : "Biaya adalah engorbanan sumber ekonomi, yang diukur satuan mata uang yang telah terjadi atau kemungkinan yang akan terjadi untuk tujuan tertentu" sedangkan (Hansen dan Mowen , 2000) menyatakan : “ Biaya adalah kas atau ekuivalen kas yang dikorbankan untuk mendapatkan barang atau jasa yang diharapkan memberi manfaat saat ini atau di masa datang agi organisasi".

Setiap pengeluaran biaya operasional dicatat oleh masing - masing bagian dan kemudian dilaporkan kepada bagian Administrasi. Untuk Bagian Mekanik, segala bentuk pengeluaran biaya operasional yang diperlukan untuk pemeliharaan kendaraan, seperti : pembelian material, spare part, dsb, ilakukan langsung oleh Direktur. Pengeluaran 
biaya ini mendapat perlakuan yang sama seperti biaya - biaya lainnya.

\section{Tujuan Penelitian}

Tujuan dari penelitian ini adalah sebagai berikut :

1. Untuk mendapatkan gambaran secara jelas mengenai penerapan sistem perencanaan dan pengawasan biaya operasional dalam praktek perusahaan dan membandingkannya dengan teori - teori yang berlaku umum.

2. Untuk mengembangkan wawasan dan pengetahuan, khususnya dalam bidang pengawasan biaya operasional.

3. Memberikan sumbangan pemikiran yang kiranya berguna bagi manajemen perusahaan dalam upaya meningkatkan efisiensi perusahaan.

\section{METODOLOGI PENELITIAN}

Untuk memperoleh data yang yang bersifat teoritis dan praktis, maka digunakan metode penelitian sebagai berikut :

1. Penelitian Kepustakaan

Penelitian Kepustakaan adalah penelitian yang dilakukan dengan jalan mengumpulkan informasi informasi yang diperlukan melalui buku - buku akuntansi literatur literatur, artikel serta buku - buku yang ada hubungannya dengan masalah yang dibahas. Metode ini bersifat teoritis.

2. Penelitian Lapangan

Penelitian Lapangan adalah penelitian yang dilakukan dengan cara mengadakan penelitian langsung pada objek yang diteliti untuk memperoleh data yang berhubungan dengan penulisan tentang penelitian ini. Penelitian ini dilakukan dengan pengamatan dan wawancara langsung kepada orang - orang yang ada hubungannya dengan masalah yang dibahas.

\section{Metode Analisis}

Metode yang digunakan untuk menganalisis masalah yang dihadapi perusahaan adalah :

1. Metode Deskriptif

Metode Deskriptif adalah metode dengan lebih dahulu mengumpulkan data yang ada dari hasil penelitian kemudian diklasifikasi, dianalisis dan untuk selanjutnya diinterpretasikan sehingga memberikan suatu gambaran atau keterangan yang lengkap tentang masalah yang dihadapi.

2. Metode Deduktif

Metode Deduktif adalah metode analisis dengan menggunakan teori yang berlaku umum, sebagai dasar untuk dibandingkan dengan praktek praktek yang berlaku dalam perusahaan yang diteliti.

\section{IV.HASIL DAN PEMBAHASAN}

Berdasarkan pengumpulan data, diperolehlah gambaran umum mengenai penyusunan anggaran biaya operasional dan pelaksanaan pengawasan pada UD. Saroha Serbelawan. Berikut ini adalah analisis dan evaluasi terhadap pengawasan biaya operasional pada UD. Saroha Serbelawan :

\section{A. Analisis dan Evaluasi Penyusunan Anggaran Biaya Operasional}

Biaya operasional UD. Saroha Serbelawan disusun oleh Bagian Administrasi yang memiliki fungsi akuntansi, dengan bantuan data dan informasi yang tercakup anggaran dan realisasi anggaran tahun sebelumnya. Pada perusahaan ini Bagian Administrasi memiliki fungsi akuntansi. Hal ini dimaksudkan untuk terciptanya penyusunan anggaran yang realistis, karena data dan informasi perusahaan terdapat pada data akuntansi. Dengan berpedoman pada tahun - tahun yang telah lewat perusahaan membuat anggaran yang lebih baik untuk periode selanjutnya.

Penyusunan anggaran biaya operasional dalam perusahaan ini melibatkan setiap bagian yang dalam perusahaan, yang diihubungkan dengan ruang lingkup aktivitas aktivitas bagian - bagian yang terkait. Prosedur dan metode anggaran dipergunakan 
untuk mempersiapkan, menilai, mempertimbangkan dan memutuskan pada rapat kerja tentang kelayakan anggaran yang disusun.

Menurut penilaian peneliti, sistem dan prosedur penyusunan anggaran biaya operasional yang dilakukan UD. Saroha Serbelawan, tidak sepenuhnya memperhatikan faktor - faktor yang mempengaruhi biaya operasional. Perusahaan lebih memperhatikan dan mempertimbangkan faktor - faktor intern yang dapat mempengaruhi biaya operasional dalam penyusunan anggaran biaya operasional.

Dengan kata lain, perusahaan kurang memperhitungkan faktor - faktor ekstern seperti ; faktor - faktor perubahan ekonomi, tingkat inflasi,keadaan sosial masyarakat dan aktivitas perusahaan dapat berjalan sesuai dengan yang telah direncanakan. Dalam prakteknya, anggaran biaya operasional yang dijadikan sebagai pedoman atas pelaksanaan aktivitas perusahaan tidak pernah dapat direalisasi dengan sempurna. Artinya, dalam setiap pelaksanaan anggaran biaya operasional akan selalu ditemukan, penyimpangan penyimpangan, baik itu yang bersifat menguntungkan atau yang bersifat merugikan. Untuk itu sebagai tindak lanjut atas pengawasan yang dilakukan terhadap pelaksanaan anggaran biaya operasional, perlu dilakukan suatu analisis terhadap pelaksanaan tersebut. Hal ini dilakukan untuk melihat bagaimana penyimpangan itu terjadi dan kemudian diambil tindakan korektif yang diperlukan agar tidak terulang lagi pada periode selanjutnya.Berdasarkan pengamatan yang dilakukan pada UD. Saroha Serbelawan, dapat dilihat bahwa pengawasan biaya operasional dilakukan dengan menggunakan anggaran sebagai alat pengawasan. Pelaksanaan kegiatan operasional perusahaan berpedoman pada anggaran tersebut. Dari hasil laporan realisasi biaya operasional yang diperoleh dari UD. Saroha dapat dilihat bahwa walaupun pelaksanaan anggaran biaya operasional telah diawasi sedemikian rupa, namun tetap saja terdapat penyimpangan penyimpangan dalam penggunaan biaya operasional ini dari yang sudah dianggarkan. sebagainya dalam penyusunan anggaran biaya operasionalnya. Padahal dalam kondisi perekonomian sekarang ini, faktor - faktor ekstern ini, cenderung lebih kuat dalam mempengaruhi biaya operasional yang digunakan perusahaan, dibandingkan faktor faktor intern. Sehingga menurut penilaian peneliti, penyusunan anggaran biaya operasional yang dilakukan oleh UD. Saroha Serbelawan tidak realisitis bila dihubungkan dengan kondisi perekonomian pada saat sekarang ini.

\section{IV.B. Analisis dan Evaluasi Pengawasan Biaya Operasional}

Pengawasan terhadap pelaksanaan anggaran biaya operasional dilakukan untuk meyakinkan dan menjamin agar kegiatan atau

Lebih lanjut untuk mengetahui bagaimana pelaksanaan pengawasan biaya operasional yang dilakukan oleh UD. Saroha Serbelawan, maka dicoba membuat suatu analisis perbandingan antara anggaran biaya operasional yang terjadi pada tahun anggaran 2004 pada tabel berikut ini :

UD. Saroha Serbelawan

Penyimpangan Biaya Operasional Tahun 2004 Dalam Ribuan Rupiah

\begin{tabular}{|c|c|c|c|c|c|}
\hline \multirow[t]{2}{*}{$\begin{array}{l}\mathbf{N} \\
\text { o. }\end{array}$} & \multirow[t]{2}{*}{$\begin{array}{c}\text { Biaya } \\
\text { Operasional }\end{array}$} & \multirow{2}{*}{$\begin{array}{c}\text { Ang } \\
\text { gara } \\
\text { n } \\
(\mathbf{R p} . \\
\text { ) } \\
\end{array}$} & \multirow{2}{*}{$\begin{array}{c}\text { Reali } \\
\text { sasi } \\
\text { (Rp.) }\end{array}$} & \multicolumn{2}{|c|}{$\begin{array}{c}\text { Penyimpang } \\
\text { an }\end{array}$} \\
\hline & & & & (Rp.) & $\%$ \\
\hline 1 & Gaji dan Upah & & & & \\
\hline 1 & Gaji Pegawai & 120. & 145. & 25.00 & 20,8 \\
\hline 2 & Upah Karyawan & 000 & 000 & 0 & 33 \\
\hline & & 144. & 166. & 22.24 & 15,4 \\
\hline & & 000 & 243 & 3 & 46 \\
\hline \multirow{2}{*}{\multicolumn{2}{|c|}{ Sub Total }} & 264. & 311. & 47.24 & 17,8 \\
\hline & & & 243 & & \\
\hline II & Biaya & & & & \\
\hline 1 & Pemasaran & 26.2 & 28.3 & 2.097 & 7,97 \\
\hline 2 & Biaya Komisi & 80 & 77 & 1.972 & 9 \\
\hline & Penjualan & 4.00 & 5.79 & & 49,3 \\
\hline & $\begin{array}{l}\text { Biaya Cetak } \\
\text { Kalender }\end{array}$ & 0 & 2 & & \\
\hline \multirow{2}{*}{\multicolumn{2}{|c|}{ Sub Total }} & 30.2 & 34.3 & 4.069 & 13.4 \\
\hline & & & & & \\
\hline I & $\begin{array}{l}\text { blaya Aammstras } \\
\text { dan Umum }\end{array}$ & 75.1 & 81.1 & 6.025 & 8,02 \\
\hline 1 & Biaya Perjalanan & 00 & 25 & 31.42 & 2 \\
\hline 2 & Biaya Pemeliharaan & 42.0 & 73.4 & 0 & 74,8 \\
\hline 3 & Bus & 00 & 20 & 2.550 & 09 \\
\hline 4 & Biaya Pemeliharaan & 14.0 & 16.5 & 1.432 & 18,2 \\
\hline 5 & Inventaris Kantor & 00 & 50. & 7.731 & 14 \\
\hline 6 & Biaya Pemeliharaan & 7.00 & 8.43 & 2.200 & 20,4 \\
\hline 7 & Gedung & 0 & 2 & 1.489 & 57 \\
\hline 8 & Biaya Asuransi Bus & & & 2.286 & \\
\hline
\end{tabular}




\begin{tabular}{|c|c|c|c|c|c|}
\hline 9 & Biaya STNK & 20.0 & 27.7 & 1.179 & 38,6 \\
\hline 1 & Biaya PKB & 00 & 31 & 1.827 & 55 \\
\hline 0 & Biaya PBB & 10.0 & 12.2 & 695 & 22 \\
\hline 1 & Biaya, Air, Listrik & 00 & 00 & & 3,91 \\
\hline 1 & dan Telepon & 38.0 & 39.4 & & 8 \\
\hline & Biaya Alat - Alat & 00 & 89 & & 4,57 \\
\hline & Tulis Kantor & 5.00 & 7.28 & & 2 \\
\hline & Biaya Umum Lain - & 0 & 6 & & 6,37 \\
\hline & Lain & 18.5 & 19.6 & & 2 \\
\hline & & 00 & 79 & & 20,3 \\
\hline & & 9.00 & 10.8 & & 34,7 \\
\hline & & 0 & 27 & & 5 \\
\hline & & 2.00 & 2.69 & & \\
\hline & & 0 & 5 & & \\
\hline & Total & 240. & 299. & 58.83 & 24,4 \\
\hline & & 600 & 434 & 4 & 53 \\
\hline I & Biaya & & & & \\
\hline $\mathbf{V}$ & Penyusutan & 17.5 & 19.2 & 1.734 & 9,88 \\
\hline 1 & Biaya Penyusutan & 50 & 84 & 47.35 & 0 \\
\hline 2 & Gedung & 116. & 163. & 9 & 40,2 \\
\hline 3 & Biaya Penyusutan & 000 & 359 & 2.673 & 86 \\
\hline & Kendaraan dan & 3.00 & 5.67 & & 89,1 \\
\hline & Mesin & 0 & 3 & & \\
\hline & $\begin{array}{l}\text { Biaya Penyusutan } \\
\text { Inventaris Kantor }\end{array}$ & & & & \\
\hline \multicolumn{2}{|c|}{ Sub Total } & $\begin{array}{l}136 . \\
550\end{array}$ & $\begin{array}{l}188 . \\
316\end{array}$ & $\begin{array}{c}51.76 \\
6\end{array}$ & $\begin{array}{c}37,9 \\
09\end{array}$ \\
\hline \multirow{2}{*}{\multicolumn{2}{|c|}{ Total }} & 671. & 833. & 161.9 & 24,1 \\
\hline & & 430 & 342 & 12 & 14 \\
\hline
\end{tabular}

Secara keseluruhan biaya operasional mengalami kenaikan sebesar Rp.161.912.000 atau $24,114 \%$ dari total biaya yang digunakan. Kenaikan ini dapat dianalisis pada masing masing jenis biaya operasional sebagai berikut

1. Biaya gaji dan upah, yaitu gaji eksekutif, gaji pegawai dan upah karyawan, dalam realisasinya mengalami kenaikan dari yang sudah dianggarkan. Realisasi biaya gaji dan upah yang digunakan sebesar Rp.311.243.000 ini menyebabkan terjadinya penyimpangan yang merugikan sebesar Rp.47.243.000 menurut informasi yang diperoleh dari perusahaan, hal ini secara umum terjadi karena adanya kebijakan perusahaan untuk menaikkan gaji eksekutif dan gaji pegawai sebagai akibat dari krisis ekonomi yang masih berlangsung pada saat ini. Krisis ekonomi ini telah menyebabkan naiknya harga harga kebutuhan secara umujm sehingga pegawai menuntut kenaikan gaji. Sedangkan kenaikan upah karyawan lebih disebabkan oleh meningkatnya aktifitas operasional perusahaan pada tahun 2004 adanya penambahan jumlah kendaraan dan mesin - mesin diluar perencanaan, mengakibatkan naiknya jumlah pengeluaran untuk upah karyawan.

2. Pada biaya pemasaran juga mengalami penyimpangan yang sifatnya merugikan realisasi biaya pemasaran sebesar Rp.34.349.000 hal ini telah menyebabkan terjadinya penyimpangan pada biaya ini sebesar Rp.4.069.000 atau 13,437\% dari biaya yang dianggarkan yaitu : Rp.30.280.000 penyimpangan pada biaya pemasaran, terutama komisi penjualan, terjadi sebagai aktiva dari meningkatnya jumlah kontrak pada tahun anggaran 2004. Penyimpangan pada biaya iklan/reklame, dan biaya cetak kalender disebabkan oleh naiknya tingkat harga - harga secara umum sebagai akibat dari krisis ekonomi, sehingga menyebabkan naiknya tarif iklan dan biaya percetakan.

3. Biaya administrasi dan umum, mengalami penyimpangan yang paling besar dari jenis biaya operasional lainnya. Biaya administrasi dan umum direalisasikan sebesar Rp.299.434.000 sedangkan jumlah biaya administrasi dan umum dianggarkan sebesar Rp.240.600.000 sehingga terdapat penyimpangan yang merugikan sebesar Rp.58.834.000 atau sebesar 24,453\% dari jumlah biaya yang dianggarkan. Pengaruh krisis ekonomi yang telah menyebabkan kenaikan harga - harga secara umum masih nampak jelas mempengaruhi penyimpangan yang terjadi pada realisasi biaya adminitrasi dan umum, terutama pada biaya pemeliharaan bus, gedung, inventaris kantor, biaya alat -alat tulis kantor dan biaya asuransi. Tingginya harga - harga material untuk pemeliharaan kendaraan dan mesin - mesin dan meningkatnya aktivitas operasional perusahaan diluar perencanaan. Biaya perjalanan dan biaya umum yang lain menyimpang merugikan sebagai akibat dari meningkatnya aktivitas operasional perusahaan yang tidak direncanakan tersebut. Biaya STNK dan pajak - pajak menyimpang akibat keterlibatan penyelesaian administrasi dengan instansi terkait oleh Bagian Adminitrasi. Sehingga perusahaan harus mengeluarkan biaya 
tambahan akibat keterlambatan ini. Sedangkan biaya air listrik dan telepon mengalami penyimpangan karena adanya pegawai yang menggunakan fasilitas telepon untuk urusan - urusan pribadi, sehingga perusahaan harus menggunakan biaya yang lebih besar dari yang dianggarkan.

4. Biaya perusahaan aktiva tetap juga mengalami penyimpangan dalam realisasinya. Anggaran untuk biaya ini sebesar Rp.136.550.000 dan direalisasikan sebesar Rp.188.316.000 sehingga terdapat penyimpangan yang merugikan sebesar Rp.51.766.000 atau 37,909\% dari biaya yang dianggarkan. Banyaknya biaya perbaikan yang dikapitalisasikan ke harga perolehan gedung, kendaraan dan inventaris kantor terjadi pada tahun anggaran 2004, telah menyebabkan naiknya angka penyusutan pada tahun tersebut. Tingginya biaya yang dikapitalisasikan tersebut juga terjadi sebagai akibat dari krisis ekonomi yang masih berlanjut.

Berdasarkan hasil dari krisis perbandingan antara realisasi biaya operasional dengan anggaran biaya operasional yang disusun untuk masing masing jenis biaya operasional, maka dapat dilihat adanya pemborosan yang terjadi dalam kegiatan operasional perusahaan pada tahun anggaran 2004. Ini dapat dilihat dari realisasi biaya operasional yang terjadi, menyimpang merugikan dari yang telah dianggarkan. Yang berarti bahwa pengawasan yang dilakukan belum memberikan keyakinan dan jaminan bahwa tujuan perusahaan yang dituangkan dalam anggaran dapat dicapai. Penyimpangan pada UD. Saroha Serbelawan, sifatnya merugikan karena seluruh biaya operasional direalisasikan melebihi anggaran yang ditetapkan.

Dari hasil analisis itu, dapat diketahui bahwa penyebab utama terjadinya penyimpangan biaya operasional pada UD. Saroha Serbelawan adalah kurangnya data dan informasi yang dimiliki perusahaan untuk memprediksi keadaan perekonomian di masa yang akan datang. Dengan kata lain bahwa perusahaan belum memiliki suatu alat untuk mendapatkan estimasi yang tepat mengenai keadaan perekonomian di masa depan, sehingga penyusunan anggaran yang dilakukan oleh UD. Saroha Serbelawan melalui Bagian Administrasi menjadi tidak realistis. Disamping itu kurangnya koordinasi kerja yang baik antara bagian - bagian dalam perusahaan dapat menyebabkan terjadinya penyimpangan dalam realisasi biaya operasional.

Pengawasan yang dilakukan oleh UD. Saroha Serbelawan dengan menggunakan anggaran ini, tentunya sangat didukung oleh kendala data akuntansinya. Data akuntansi tentunya akan kurang mempunyai arti tanpa didukung oleh sistem wewenang dan prosedur pencatatan yang baik. Dengan adanya sistem otorisasi penggunaan dana anggaran biaya operasional pada masing - masing bagian dalam perusahaan, masih memberikan kemungkinan terjadinya penyimpangan dalam realisasi biaya operasional dari yang telah dianggarkan.

Sehingga dinilai bahwa penyimpangan dalam realisasi biaya operasional pada UD. Saroha Serbelawan, terjadi akibat dari kurangnya pengawasan yang dilakukan perusahaan terhadap pelaksanaan anggaran biaya operasional. Penyimpangan yang terjadi seperti hasil analisa itu kiranya dijadikan bahan acuan untuk periode yang akan datang atau setidaknya kejadian tersebut diantisipasi dan dievaluasi dengan baik sehingga tidak terulang lagi pada periode selanjutnya.

\section{KESIMPULAN DAN SARAN}

\subsection{Kesimpulan}

1. Adanya penyimpangan dalam realisasi biaya operasional pada tahun anggaran 2004, terjadi karena anggaran biaya operasional yang disusun untuk tahun anggaran 2004 tidak realistis karena kurang memperhitungkan faktor - faktor ekstern yang dapat mempnegaruhi biaya operasional.

2. Penyimpangan yang terjadi dalam realisasi biaya operasional pada tahun anggaran 2004 , juga disebabkan oleh kurangnya pengwasan akuntansi yang dilakukan oleh UD. Saroha Serbelawan 
terhadap biaya operasional, kurang didukung oleh sistem wewenang dan prosedur pencatatan yang baik.

3. Proses penyusunan anggaran biaya operasional pada UD. Saroha Serbelawan sistem dan prosedur penyusunannya, telah melibatkan semua bagian-bagian yang ada untuk berpartisipasi dalam penyusunan anggaran biaya operasional tersebut. Penyusunan anggaran tersebut dilakukan dengan mempertimbangkan faktor - faktor intern yang mempengaruhi biaya operasional, tetapi kurang mengantisipasi dan memperhitungkan faktor - faktor ekstern seperti : faktor perubahan ekonomi, tingkat inflasi dan sebagainya, sehingga anggran yang disusun menjadi tidak realistis jika dihubungkan dengan keadaan perekonomian pada saat itu.

4. Pengawasan dengan anggaran pada UD. Saroha Serbelawan yang dievaluasikan pada akhir tahun menunjukkan adanya penyimpangan yang cukup material dalam relaisai biaya operasional pada tahun anggaran 2004. Hal ini dapat dibuktikan dengan adanya persentase penyimpangan yang terjadi jauh di atas batas toleransi yaitu 5\% sedangkan anggaran pada suatu perusahaan dikatakan sangat memuaskan apabila persentase yang digambarkan pada laporan realisasi berkisar 95\% dari apa yang tercantum dalam anggaran.

\subsection{Saran}

Adapun saran - saran yang bisa diberikan sebagai bahan pertimbangan bagi pimpinan perusahaan dalam menghadapi masalah yang dihadapai adalah sebagai berikut

1. Dalam upaya penyusunan anggaran biaya operasional yang lebih realistis, hendaknya perusahaan melakukan penelitian yang lebih cermat terhadap semua faktor - faktor yang mempengaruhi biaya operasional, baik faktor intern maupun faktor ekstern. Terutama pada faktor ekstern hendaknya perusahaan melakukan pertimbangan dan perhitungan yang lebih akurat karena dalam kondisi perekonomian sekarang ini ternyata faktor - faktor diluar perusahaan ini lebih kuat dalam mempnegaruhi setiap kebijakan perusahaan.

2. Dalam hal pengukuran efisiensi kinerja perusahaan, anggaran memgang peranan penting. Oleh karena itu anggaran biaya operasional yang telah dierencanakan bdiawasi sebaik - baiknya karena jika tidak, kelagsungan jalannya operasional perusahaan akan terganggu.

3. Untuk mendukung kendala data akuntansi perusahaan, sebaiknya perusahaan melakukan pemisahan tugas dalam pengelolaan biaya operasional perusahaan, yaitu pemisahan tugas antara yang berwenang mengotorisasi, menggunakan dan mencatat setiap penggunaan biaya operasional. Karena dengan demikian biaya operasional akan dapat lebih dikendalikan, bahkan bila mungkin akan dapat ditekan.

\section{V.I. REFERENSI}

Anthony, Robert N., et.al., Management Control System, $5^{\text {th }}$ Edition, Sistem Pengendalian Manajemen, Alih Bahasa Agus Maulana, Edisi Kelima, Erlangga, Jakarta , 1990.

Hansen Don R. And Mowen Maryanne M., Akuntansi Manajemen, Alih Bahasa Ancella A. Hermanan, Jilid Satu, Edisi Keempat, Cetakan Keempat : Erlangga, Jakarta, 2000.

Matz, Adolph, et. al., Cost Accounting, Planning and Control, $8^{\text {th }}$ Edition, Akuntansi Biaya, Perencanaan dan Pengendalian, Alih Bahasa Herman Wibowo, Jilid Satu, Edisi Kesembilan, Erlangga, Jakarta, 1991.

Mulyadi, Akuntansi Biaya, Edisi Keempat, Cetakan Pertama : BPFE, Yogyakarta, 1990.

Nafarin, M., Budgeting, Perencanaan Kerja, Pengkoordinasian Kerja, Pegawasan Kerja, Edisi Pertama, Cetakan Pertama : Salemba Empat, Jakarta, 2000.

Terry, George R., Guide to Management, 
Prinsip - Prinsip Manajemen,

Penerjemah J. Smith D.F.M., Cetakan

Kelima ; Bumi Aksara, Jakarta, 1993. 